\begin{tabular}{c} 
International Journal of Scientific World, $5(1)(2017) 62-66$ \\
International Journal of Scientific World \\
SPC \\
Website: $\begin{array}{c}\text { ww. sciencepubco.com/index.php/IJSW } \\
\text { doi: } \\
\text { Research paper }\end{array}$ \\
\hline
\end{tabular}

\title{
Phytochemical, antimicrobial and nutritional properties of Morinda lucida benth and Nauclea latifolia leaf extracts
}

\author{
Stephen Amadin Enabulele *, Oluwatosin Amusa, Eseosa Uwadiae \\ Benson Idahosa University, Benin City, Edo State, Nigeria \\ *Corresponding author E-mail:senabulele@biu.edu.ng
}

\begin{abstract}
The leaves of two medicinal plants namely; Morinda lucida and Nauclea latifolia were investigated for their antibacterial, mineral and phytochemical properties. Results of the study showed that the aqueous and ethanolic extract of the two leaves had significant antibacterial activity against Escherichia coli, Staphylococcus aureus, Pseudomonas aeruginosa, Listeria monocytogenes and Proteus mirabilis. The biologically active constituents present in the extracts were cardiac glycosides, tannins, saponin, coumarins, reducing sugar, terpenoids, alkaloids, steroids and flavonoids. The percentage yield extracts of the respective plants were Morinda lucida leaves $12.9 \%$ for ethanol and $9.0 \%$ for aqueous extracts while Nauclea latifolia had $12.1 \%$ for ethanol and $8.4 \%$ for aqueous extracts. Results of the antibacterial activity analysis revealed that the ethanolic extracts of the two medicinal plants at different concentrations were more active against the test organisms named above than the aqueous extracts. The MIC values for the ethanolic extracts ranged between 25.0 and $100.0 \mathrm{mg} / \mathrm{ml}$ while that of aqueous extract ranged between 50.0 and $100.0 \mathrm{mg} / \mathrm{ml}$. The MBC values for ethanolic extract ranged between 50.0 and $100 \mathrm{mg} / \mathrm{ml}$ while that of aqueous extracts also ranged between 50.0 and $100 \mathrm{mg} / \mathrm{ml}$. Analysis of the mineral content of the plant leaves shows that they were rich in potassium and calcium. This study confirms that the leaf extracts have some reasonable level of antimicrobial activity and appreciable amounts of mineral content which could be beneficial to human health. The findings from this work can be further exploited for isolation and characterization of novel Phytochemical compounds which could be used in the treatment of infectious diseases especially in light of the emergence of drug-resistant microorganisms and the need to produce new effective antimicrobial agents.
\end{abstract}

Keywords: Morinda lucida; Nauclea latifolia; Antimicrobials; Phytochemicals; Medicinal Plants.

\section{Introduction}

Medicinal plants have been used as traditional treatments for numerous human diseases for thousands of years and in many parts of the world. In rural areas of developing countries, they continue to be used as the primary source(s) of medicine [7]. About $80 \%$ of the people in developing countries are reported to use traditional medicines for their health care and as such renewed interest in plant medicine, is been developed by a lot of scientists and conscious efforts are now directed at the screening of medicinal plants with a view of screening secondary metabolites and mineral that will serve as templates for the total synthesis of compounds with enhanced similar structure activity relationship [6][17].

Phytochemicals are biologically active, naturally occurring chemical compounds found in plants, which provide health benefits for humans. These compounds known as secondary plant metabolites are known to have active biological properties and their traditional usage in curing illnesses has deep root and is documented among the Nigerian native people [1].Plants are used and still being used in treating ailments such as malaria, diarrhoea, burns, gonorrhoea, stomach disorders and other infectious diseases especially in tropical Africa and in less privileged societies of the world [10]. Morinda lucida benth (Rubiaceae) which is a tropical West Africa rainforest tree and also called Brimestone is one of such plant. Stem, bark, roots and leaves infusion of Morinda lucida benth, are known to be locally used as an anti-malarial, anti-diabetic, antimicrobial and in the treatment of jaundice [19]. The plant is reputed to be one of the most used traditional medicines against fever in sub Saharan Africa [4].

Nauclea latifolia commonly known as pin cushion tree and belonging to the family Rubiaceae is also one of such plants. The leaves of Nauclea latifolia is used in the treatment of ailments such as malaria, gastrointestinal tract disorders, sleeping sickness, prolong menstrual flow, hypertension and as a chewing stick [4]. The plant is also documented to be used as a tonic and fever medicine, for toothaches, dental caries, septic mouth and diarrhoea [18].

Several drugs including some antibiotics are no longer active against targeted organisms. It has been reported that the effective lifespan of these therapeutics agents are limited [16]. Therefore, we experience antibiotic resistant organisms, and ineffective synthetic drugs. More so, majority of the orthodox drugs are both expensive and display dangerous side effects in the users. Hence, discovering and identifying new safe drugs using medicinal plants without severe side effects has become an important goal of research in biological science. It is in this context that the aqueous and ethanolic extracts of leaves of Morinda lucida (fig.1) and Nauclea latifolia (fig.2), were screened for their Phytochemical, antimicrobial and nutritional properties. 


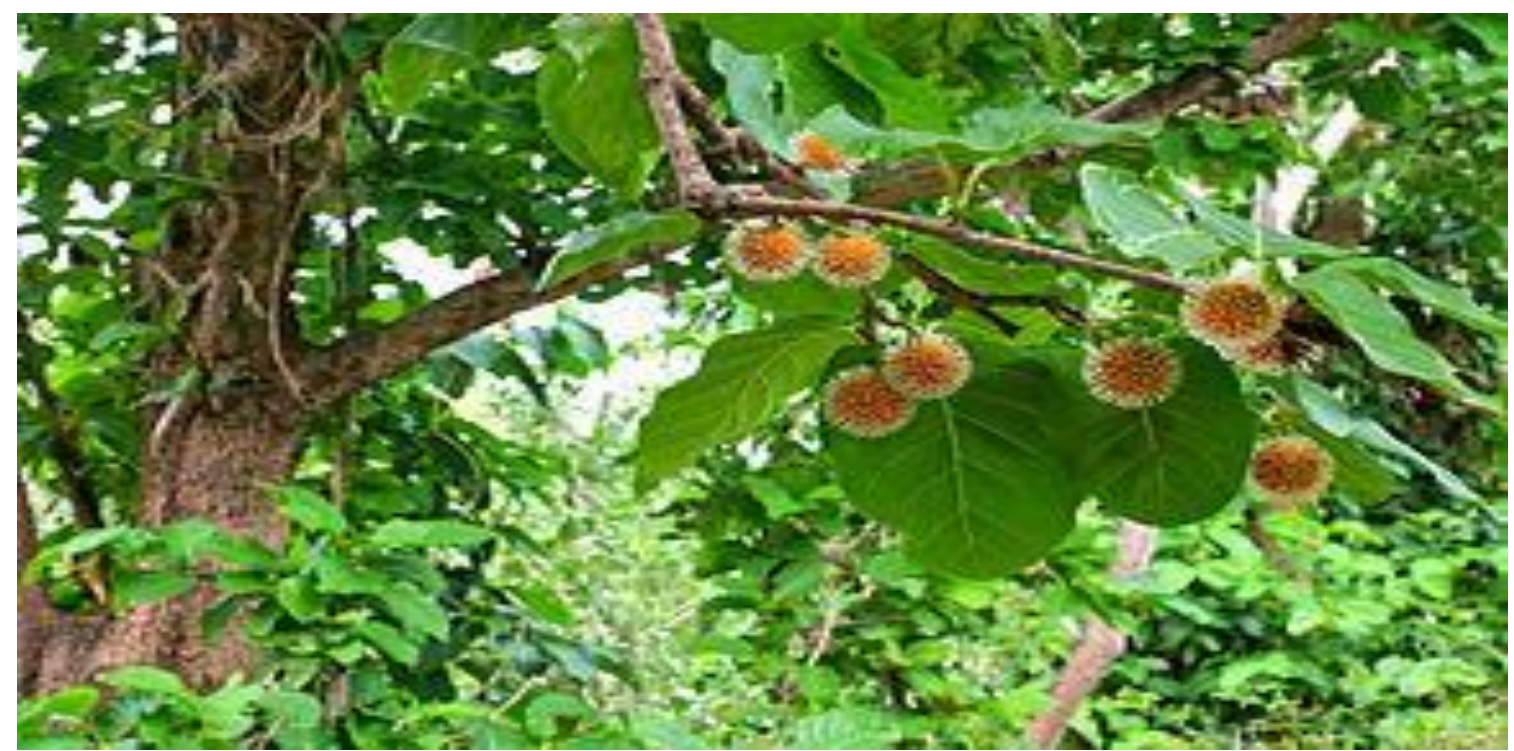

Fig. 1: Morinda lucida Leaves [4].

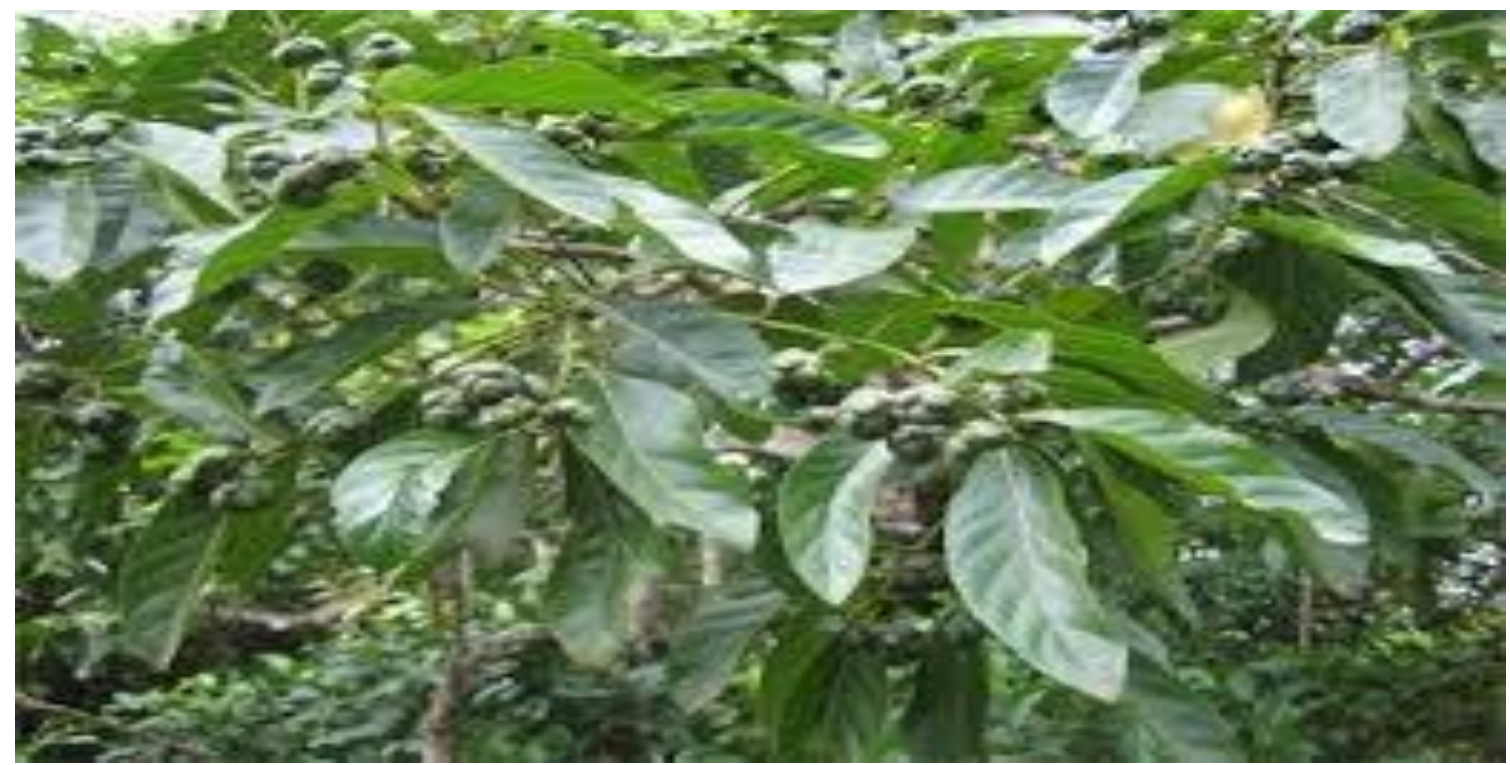

Fig. 2: Nauclea latifolia Leaves and Fruits [4].

\section{Materials and methods}

\subsection{Collection of samples}

Leaves of Morinda lucida (Brimestone tree), and Nauclea latifolia (Pin cushion tree) were collected from, Ogan, Ifo, Ogun State and were identified by Dr. O. Olorunfemi of the Department of Botany, University of Benin, Edo State.

\subsection{Preparation of samples}

The leaves were air dried for five days, after which they were milled into powder with a dry sterilized Panasonic blender model MX-JI20P.The powdered leaves were then sieved through a $2.0 \mathrm{~mm}$ filter and subsequently stored in an air tight sterile container until it was used.

\subsection{Leaf extracts preparation}

The leaf extracts were obtained by using the method of [19]. One hundred grams $(100 \mathrm{~g})$ of the powdered samples were soaked in $400 \mathrm{ml}$ of solvent in different sterile conical flasks and plugged with cotton wool. It was then wrapped with aluminium foil and shaken vigorously. The mixture was left to stand for $24 \mathrm{~h}$ in a shaking water bath maintained at $37^{\circ} \mathrm{C}$. The mixtures were then filtered using a clean muslin cloth and Whatman No.1 filter paper. Thereafter the filtrate was evaporated to dryness by means of a rotary evaporator model SM- 52CS-1 attached to a vacuum pump. The percentage yield of each of the crude extracts were determined for each solvent and estimated as dry weight (extract)/dry sample weight $\mathrm{x} 100$. The extracts were stored in an airtight container and kept in refrigerator until needed for further analysis.

\subsection{Phytochemical screening}

The Phytochemical analysis of the leaf extracts were done according to the method of [19].They were tested for the presence of flavonoids, cardiac glycosides, reducing sugars, steroids, phenolics, essential oils, tannins, saponins. terpenoids, flavonoids and steroids.

\subsection{Sources of microorganisms}

The organisms used for the investigation were clinical isolates obtained from Faith Mediplex hospital, Benin City, Edo State. The bacterial species used were Stapylococcus aureus, Listeria monocytogenes, Esherichia coli, Proteus mirabilis and Pseudomonas aeuruginosa. The isolates were re-identified by biochemical tests according to methods outlined by [8]. 


\subsection{Minimum inhibitory concentration (MIC) and min- imum bactericidal concentration (MBC)}

The method of [14] was adapted in determining the MIC and MBC of respective extracts. The MIC was determined using the tube dilution method. Standardized suspensions of the test organism was inoculated into series of sterile tubes of nutrient broth containing different concentrations of leaf extracts and incubated at $37^{\circ} \mathrm{C}$ for $24 \mathrm{~h}$. The MICs were read as the least concentration that inhibited the growth of the test organisms.

The MBCs were determined by first selecting tubes that showed no growth during MIC determination: A loopful from each tube was subculture onto extract free agar plates, incubated for another $24 \mathrm{~h}$ at $37^{\circ} \mathrm{C}$. The minimum bactericidal concentration was considered as the lowest concentration that could not produce a single bacterial colony [8].

\subsection{Mineral elements evaluation}

The recommended methods of the Association of Official Analytical Chemists [3] earlier used and enumerated by [13] were used for the determination of the nutritional and mineral content.

\section{Results and discussion}

Generallytheeffectivenessofanyantimicrobialcompounddependsontheabilityofthe antimicrobial to inhibit or stop the growth of any microorganism in the body system they infect. Because of the high genetic variability of microorganisms, they seem to however develop the ability to rapidly evade the action of antimicrobials by becoming resistant to them. It becomes necessary therefore to look for newer means of eliminating microbial threat causing infections. Percentage yield of the aqueous and ethanolic extract of the powdered leaf of Morinda lucida shown in table 1 are higher than that of the Nauclea latifolia extracts. Ethanol however seem to be the better of the two solvents used in this study. This is consistent with the results of [2] who also found ethanol to be best of all the solvents used for their analysis.

The biological function of flavonoids includes protection against allergies, inflammation, free radicals, platelet aggregation, microbes, ulcers, hepatoxins, viruses and tumours. These plants also have quantity of saponin content. Some of the general characteristics of saponin include formation of foam in aqueous solutions, haemolytic activity cholesterol binding properties and bitterness [20]. Apart from saponin other metabolite constituents of the se- lected medicinal plants detected include the alkaloids and tannin. Alkaloids ranked the most efficient therapeutically significant plant substance. Pure isolated plant alkaloids and their synthetic derivatives are used as basic medicinal agents for their analgesic, anti-plasmodic and bactericidal effects. They exhibited marked physiological activity when administered to animals. Tannin has been identified as a Phytochemical that helps in hastening the healing of wounds and inflamed mucous membrane [20]. The presence of tannin in some of the selected plants reported (Table 2) strongly supports its use in treating wounds, burns and haemorrhoids in herbal medicine.

The antimicrobial activity of Morinda lucinda and Nuclea latifolia are presented in table 3 and table 4 . The ethanol crude extracts of both leaves inhibited the growth of the five (5) test organisms at varied concentration. However the aqueous extracts inhibited all the test organisms at $200 \mathrm{mg} / \mathrm{ml}$ and $100 \mathrm{mg} / \mathrm{ml}$ except Staphlococcus aureus for Nauclea latifolia and Listeria monocytogenes for Morinda lucinda. The results are in line with the report of [13] who reported that the susceptibility of bacteria to crude plant extracts varies according to strain and specie.

From the results, the ethanol extracts had higher zones of inhibition against all test organisms at varying concentrations as compared to the aqueous extracts. Reports by [11] and [9] have also suggested the efficacy of alcohol based extracts against bacteria more than water based extracts. The percentage of effectiveness showed higher values for the ethanol extracts of both leaves at the concentration of $200 \mathrm{mg} / \mathrm{ml}$ as compared to the antibiotic control except for Proteus mirabilis and Listeria monocytogenes for Morinda lucinda and Staphylococcus aureus and Proteus mirabilis for Nauclea latifolia. The ethanol extracts at $100 \mathrm{mg} / \mathrm{ml}$ and aqueous extracts at varying concentrations despite having lower values showed that they were more than half as effective as the control. There were no zones recorded at $50 \mathrm{mg} / \mathrm{ml}$ for both extracts of the leaves suggesting that the dose was too small to have an effect on the test bacteria.

Minimum inhibitory concentration values for this study are presented in table 5.The MIC for ethanol extract for both leaves ranged from 25 to $50 \mathrm{mg} / \mathrm{ml}$ while the aqueous extract ranged from 50 to $100 \mathrm{mg} / \mathrm{ml}$. the values obtained are reasonable to suggest the pharmacological relevance of the leaf extracts. Differences in effectiveness of the extracts could be attributed to their impure form as the crude nature of the extracts may contain substances which may not have any antibacterial activity. This observation was also reported by [12].

Table 1: Percentage Yield

\begin{tabular}{lllllll}
\hline \multirow{2}{*}{ Medicinal Plant } & Ethanol & & & Aqueous & & \\
& Leaf powder $(\mathrm{g})$ & Extract $(\mathrm{g})$ & Yield $(\%)$ & Leaf powder $(\mathrm{g})$ & Extract $(\mathrm{g})$ & Yield $(\%)$ \\
\hline Morinda lucida & 100 & 12.9 & 12.9 & 100 & 9.0 & 9.0 \\
Nauclea latifolia & 100 & 12.1 & 12.1 & 100 & 8.4 & 8.4 \\
\hline
\end{tabular}

The antimicrobial effect of all these extracts is due to the phytochemical constituents present in them. Morinda lucida and Nauclea, latifola leaves are rich in phytonutrient such as flavonoids, phenolic compound tannins, saponin, terpernoids, cardiac glycosides, coumarins and alkaloids which have been reported by [5].

Table 2: Phytochemical Constituents of Morinda lucida and Nauclea latifolia

\begin{tabular}{|c|c|c|c|c|}
\hline Phytochemicals & $\begin{array}{l}\text { Ethanol } \\
\text { Morinda lucida }\end{array}$ & Nauclea latifolia & $\begin{array}{l}\text { Aqueous } \\
\text { Morinda lucida }\end{array}$ & Nauclea latifolia \\
\hline Cardiac Glycosides & +++ & ++ & + & + \\
\hline Tannins & ++ & +++ & - & ++ \\
\hline Saponins & ++ & + & ++ & ++ \\
\hline Coumarins & + & + & + & + \\
\hline Reducing Sugars & ++ & ++ & ++ & - \\
\hline Terpenoids & ++ & +++ & + & + \\
\hline Alkaloids & +++ & +++ & + & ++ \\
\hline Steriods & + & - & - & - \\
\hline Flavonoids & ++ & + & ++ & ++ \\
\hline
\end{tabular}

Key: + = slightly present; ++ = moderately present; +++ = highly Present; -- = absent 
Table 3: Antimicrobial Activity of Morinda lucinda

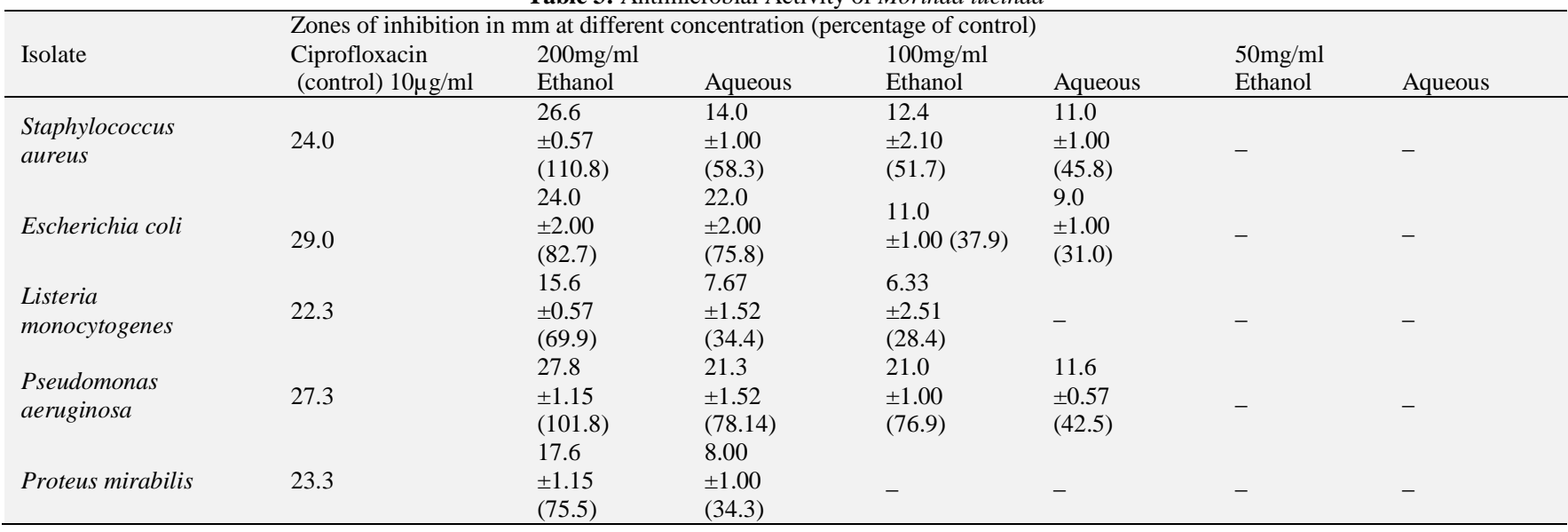

Table 4: Antibacterial Activity of Nauclea latifolia Leaf Extracts

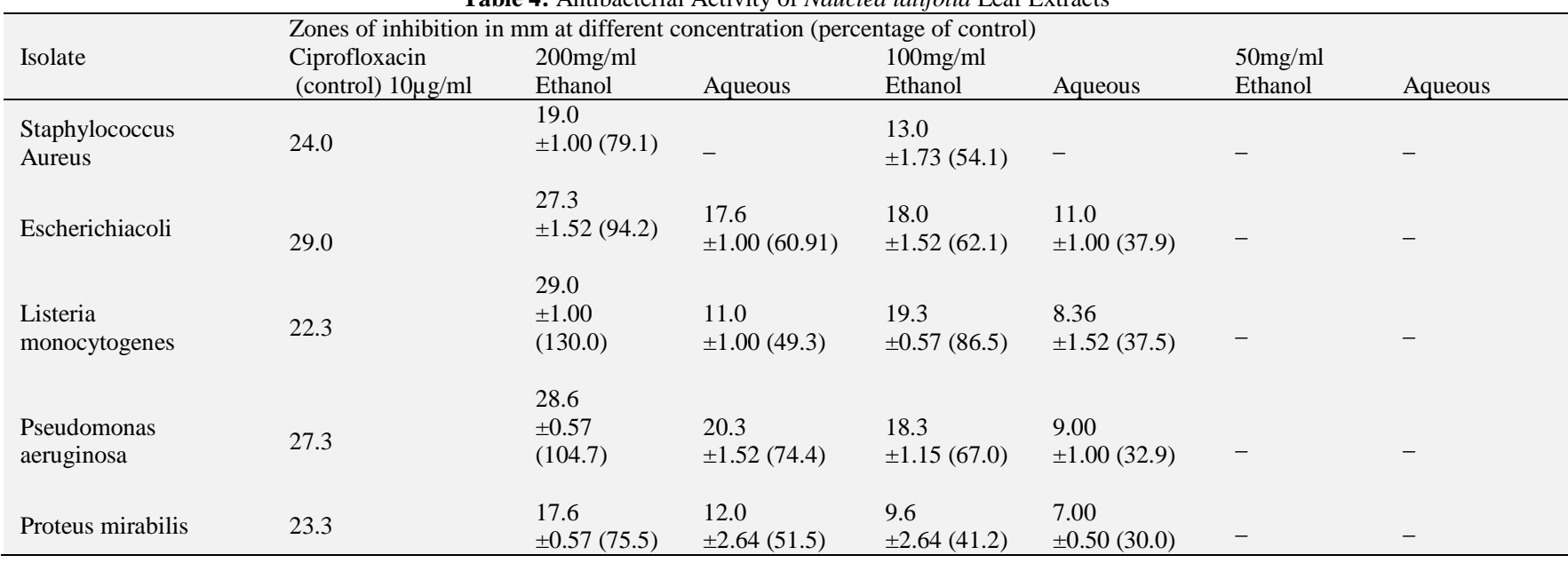

Table 5: Minimum Inhibitory Concentration (MIC) and Minimum Bacterial Concentration (MBC) of Morinda lucinda and Nauclea latifolia Leaf Extracts in $\mathrm{Mg} / \mathrm{Ml}$

\begin{tabular}{|c|c|c|c|c|c|c|c|c|}
\hline \multirow{3}{*}{ Isolates } & \multicolumn{4}{|c|}{ Morinda lucinda } & \multicolumn{4}{|c|}{ Nauclea latifolia } \\
\hline & \multicolumn{2}{|c|}{ Ethanol } & \multicolumn{2}{|c|}{ Aqueous } & \multicolumn{2}{|c|}{ Ethanol } & \multicolumn{2}{|c|}{ Aqueous } \\
\hline & MIC & $\mathrm{MBC}$ & MIC & $\mathrm{MBC}$ & MIC & $\mathrm{MBC}$ & MIC & $\mathrm{MBC}$ \\
\hline $\begin{array}{l}\text { Staphylococcus } \\
\text { aureus }\end{array}$ & 50 & 50 & 50 & 50 & 100 & 100 & 100 & 100 \\
\hline Escherichiacoli & 50 & 50 & 50 & 50 & 50 & 50 & 100 & 100 \\
\hline $\begin{array}{l}\text { Listeria } \\
\text { monocytogenes }\end{array}$ & 100 & 100 & 100 & 100 & 25 & 50 & 100 & 100 \\
\hline $\begin{array}{l}\text { Pseudomonas } \\
\text { aeruginosa }\end{array}$ & 25 & 50 & 50 & 50 & 25 & 50 & 100 & 100 \\
\hline Proteus mirabilis & 100 & 100 & 100 & 100 & 50 & 50 & 50 & 50 \\
\hline
\end{tabular}

Table 6: Mineral Content of the Plant Extracts and Recommended Daily Allowance (RDA) in Mg/100ml

\begin{tabular}{llll}
\hline \multirow{2}{*}{ Minerals } & Contents $(\mathrm{mg} / 100 \mathrm{~g})$ & \\
& Morinda lucinda & Nauclea latifolia & RDA $\left(\% \mathrm{RDA}^{\mathrm{A}}\right)$ \\
\hline Iron & 53.5 & 36.3 & 400 \\
Zinc & 24.2 & 31.3 & 15 \\
Calcium & 105.9 & 120.3 & 3500 \\
Potassium & 428.3 & 374.6 & 18 \\
Copper & 2.5 & 2.7 & 90 \\
Manganese & 16.8 & 19.2 & 0.23 \\
\hline
\end{tabular}

${ }^{\mathrm{A}}=$ Recommended daily allowance [15]

The mineral analyses for the leaves of Nauclea latifolia and Morinda lucida shows the presence of micro and macro nutrients in good amounts. Potassium and calcium were the most abundant nutrients in both plants. However, the elemental concentrations in both leaves may be a reflection of the elemental composition of their parent soil.

\section{Conclusion}

Conclusively, it was noted that the aqueous and ethanol crude leaf extracts of Nauclea latifolia and Morinda lucida contained im- portant nutritional and bioactive compounds with high antibacterial activity against the selected test organisms. Thus, this study reveals the therapeutic properties of the selected plants, which could be of considerable interest in the development of new drugs. Further studies however are needed to isolate and purify some of the antimicrobial agents present in the plants so as to ascertain their full potential and assist in the effective treatment of common ailments ravaging the populace. 


\section{References}

[1] Adeboye, M.F., Akinpelu, D.A. and Okoh, A.(2008).The bioactive and phytochemical properties of Garcinia kola (Heckel) seed extract on some pathogens. African journal of Biotechnology, 7(21): 3934-3938.

[2] Ahmad I, Mehmood Z, Mohammad F. (1998). Screening of some Indian medicinal plants for their antimicrobial properties. J. Ethnopharmacol. 62(2): 183-93 http://dx.doi.org/10.1016/s03788741(98)00055-5.

[3] AOAC (1984). Official Methods of Analysis, 14th Ed. (Association of Official Analytical Chemists), Washington DC,

[4] Bello,I.S., Oduola, T.,Adeosun, O.G.,Omisore,N.O. A.,Raheem,G.Oand Ademosun, A. A. (2009). EvaluationofantimalarialactivityofvariousfractionsofMorindalucidaleafextractand A l s t o n i a booneiStemBark,GlobalJournalofPharmacology, 3(3): 163-165

[5] Bur-

kill,H.M.(1985).TheusefulplantsofWestAfrica,Vol.1.Royalbotanical gardens,Journal of Herb Pharmacolotherapy,11-20

[6] Chintamunnee V. and Mahomoodally, M. F. (2012). "Herbal medicine commonly used against infectious diseases in the tropical island of Mauritius," Journal of Herbal Medicine, 2: 113-125, http://dx.doi.org/10.1016/j.hermed.2012.06.001.

[7] Chitme,H.R.,Chandra,RandKaushik,S.(2003).Studiesonantidiarrheal activity of Calotropis gigantean in experimental animals.Journal of Pharmaceutical Sciences, 7:70 -5.

[8] Cowan, S.T and Steel, K.J. (2004).Manual for identification of bacteria Vol. 2. $3^{\text {rd }}$ edn. Cambridge University press, London, $19-22$.

[9] Cowan, M.M. (1999). Plant products as antimicrobial agents. Clinical Microbiological, 12: 564 - 582

[10] Das,K.,Tiwari,RK.SandShrivastava,D.K.(2010). Techniques for evaluation of medicinal plant products as antimicrobial agent: current methods and future trends, "Journal of Medicinal Plants, 7(12):1797-1806.

[11] Ellof J. N (1998). Which extracts should be used for screening and isolation of antimicrobial components from plants? J. Ethnopharm., 60: 1- 8. http://dx.doi.org/10.1016/S0378-8741(97)00123-2

[12] El-Mahmood M. A. (2009), Antibacterial activity of crude extracts of Euphorbia hirta against some bacteria associated with enteric infections. J. Med. Plants Res, 3 (7): 498-505.

[13] Enabulele, S. A. and Ehiagbonare, J.E. (2011). Antimicrobial, Nutritional and Phytochemical properties of Perinari excelsa seeds. International Journal of Pharmacology and Biological Sciences, 459-470.

[14] Enabulele S. A., Oboh F. O. J. and Uwadiae E. O. (2014). Antimicrobial, Nutritional and Phytochemical Properties of Mon odora myristica Seeds. IOSR Journal of Pharmacy and Biological Sciences. 9(4 ver.111): $01-06$

[15] Eyabi, E. G. D. (2001). Understanding the product and the process. In: P. Fellows and B. Axtell (ed), A Handbook for setting up and running a small food business. Opportunities in food processing series. (Washington: ACP-EU Technical Centre for Agricultural and Rural Cooperation (CTA), pp. 29-50

[16] Mahomoodally M. F. (2013). Traditional Medicines in Africa: An Appraisal of Ten Potent African Medicinal Plants. Evidence-Based Complementary and Alternative Medicine 2013: 1-14. http://dx.doi.org/10.1155/2013/617459.

[17] Fauci, A. (1998). New and re-emerging diseases: The importance of biomedical research. Emerging Infectious Diseases, 4:3 http://dx.doi.org/10.3201/eid0403.980308

[18] Nweze N.E., (2011); In vitro anti-trypanosomal activity of Morinda lucida leaves, African Journal of Biotechnology 11(7): 812-1817.

[19] Ogundare,A.Oand Onifade.A. K., (2009). The antimicrobial activity ofMorinda lucida leaf extract on Escherichia coli. Journal of Medicinal Plants Research 3(4):319-323.

[20] Okwu, D.E. (2004). Phytochemicals and vitamin content ofindigenous species of $\mathrm{S}$ o u $\mathrm{t} \mathrm{h}$ Eastern Nigeria. Journal of SustainableAgriculturalEnvironment, 6: 30-34. 